\title{
1 Grapes and vines of the Phoenicians: morphometric analyses of pips from 2 modern varieties and Iron Age archaeological sites in the Western 3 Mediterranean
}

4 Claudia Moricca $^{1,2^{*}}$, Laurent Bouby ${ }^{3}$, Vincent Bonhomme ${ }^{3}$, Sarah Ivorra ${ }^{3}$, Guillem Pérez-Jordà ${ }^{4}$, 5 Lorenzo Nigro $^{5}$, Federica Spagnoli ${ }^{5}$, Leonor Peña-Chocarro ${ }^{6}$, Peter van Dommelen ${ }^{7}$, Laura Sadori ${ }^{2}$

$6{ }^{1}$ Department of Earth Sciences, Sapienza University of Rome, Piazzale Aldo Moro 5, 00185 Roma, Italy;

7 claudia.moricca@uniroma1.it

$8{ }^{2}$ Department of Environmental Biology, Sapienza University of Rome, Piazzale Aldo Moro 5, 00185

9 Roma, Italy

$10 \quad{ }^{3}$ ISEM (UMR 5554), Univ Montpellier, CNRS, IRD, EPHE, Montpellier, France

$11{ }^{4}$ GRAM-GIUV2015-222, Department de Prehistòria, Arqueologia i Història Antiga, Universitat de 12 València, Avda. Blasco Ibañez 28, 46010, València, Spain

$13{ }^{5}$ Department “Italian Institute of Oriental Studies - ISO”, Sapienza University of Rome, Circonvallazione 14 Tiburtina 4, 00185 Roma, Italy

$15{ }^{6}$ GI Paleoeconomía y Subsistencia de las Sociedades Preindustriales, Instituto de Historia (CSIC). Albasanz 16 26-28, E-28030 Madrid, Spain

$17{ }^{7}$ Joukowsky Institute for Archaeology and the Ancient World, Brown University, Providence, RI, USA 


\section{Abstract}

The present study aims to contribute to the investigation of the role of Phoenicians in the spreading and trade of the grapevine through the morphometric analysis of grape pips. Waterlogged and charred samples were selected from three Iron Age sites in the Western Mediterranean: Motya (Sicily, Italy), Nuraghe S'Urachi (Sardinia, Italy) and Huelva (Andalusia, Spain). While only Motya is a Phoenician foundation, all three were nevertheless associated with Phoenician expansion and cultural interaction. Ten cultivars from the "Vivaio Federico Paulsen" in Marsala (western Sicily) were chosen as modern reference material.

The key challenge was the comparison of archaeological pips preserved through different fossilization processes, which was overcome using two reference datasets of the same modern cultivars, one uncharred and one charred. Statistical analyses of pip outlines show that archaeological remains from these sites is morphologically comparable to that of modern varieties, suggesting that the archaeological finds represent domesticated grapevines.

PCA analyses allowed an inter-site comparison, showing that samples from the three sites are clearly distinguishable based on their morphology. This indicates the use of different varieties which may be due to different factors.

Our analysis represents a first step towards a better understanding of diachronic and synchronic relationship between vines grown in the ancient West Mediterranean, which could be expanded by analysing grape pips from more contexts and more sites, compared against a wider selection of modern cultivars.

Keywords: Phoenicians, viticulture, morphometry, Western Mediterranean, experimental charring

\section{Introduction}

This study aims at better understanding the role of Phoenicians in the spreading and trade of the grapevine in the Western Mediterranean through the morphometric analysis of grape pips from three Western Mediterranean sites dated to between the $9^{\text {th }}$ and the $6^{\text {th }}$ centuries B.C.

The grapevine (Vitis vinifera L.) is one of the most important fruit crops of the past and present world, both economically and culturally. The wild and cultivated forms, respectively Vitis vinifera L. subsp. sylvestris (C.C. Gmel.) Hegi and V. vinifera L. subsp. vinifera, differ by an array of traits, including their reproductive biology. Wild grapevine is dioecious and is cross-pollinated, while domesticated grapes are in most cases hermaphrodite and capable of self-pollination (Negi and Olmo, 1966; This et al., 2006). Domestication has also resulted in an increase in berry size and sugar content, which are both factors that play a key role in fermentation (Miller, 2008; Bouby et al., 2013). Differences can moreover be observed in the shape of its seeds, with wild pips being "small, robust, with a rounded outline, or cordate, with short stalks [...] almost flat ventrally with sharp angles and a strongly developed chalaza", in contrast with cultivated ones that are large, 
elongated, oval or pyriform, with a longer stalk, more rounded ventrally and less sharply sculptured (Mangafa and Kotsakis, 1996, p. 409; Levadoux, 1956; Jacquat and Martinoli, 1999).

The origins of wine production have been traced back to the Caucasus in the $7^{\text {th }}-6^{\text {th }}$ millennia (McGovern et al., 2017). It is unknown if these first wines were made from wild or cultivated grapes (Bouby et al., 2021). Nonetheless, all evidence indicates that domesticated grapes also originated there (e.g. Myles et al., 2011). Grapevine was cultivated, and probably domesticated, in South West Asia by at least the $4^{\text {th }}$ millennium BC (e.g. Miller, 2008; Fuller and Stevens, 2019). Recent studies based on morphometric analyses of grape pips also suggest an early local domestication in Greece that goes back to the Neolithic (Pagnoux et al., 2021). It is believed that new domesticated varieties were subsequently introduced in Greece during the Late Bronze Age, possibly through increased exchanges and trade with the Near East.

The importance of fruit trees in past societies is greatly correlated to their role as a source of food products with significant economic value, such as dried fruits, oil and wine. At least in some cases their cultivation was initially based on reproduction by seed, which implies a great deal of uncertainty because of the heterozygosity inherent in many fruit species, which means that seedlings often give rise to offspring that are very different from the parents (Bouby and Ruas, 2014). The switch to vegetative propagation through cuttings, marcotting and grafting is propagation of cultivars that are basically clones (Bouby and Ruas, 2014).

Grassi et al. (2003), Imazio et al. (2004), Arroyo-García et al. (2006) and more recently Riaz et al. (2008) have performed simple sequence repeats (SSR) analyses on wild and cultivated grapevines. Their results suggest the presence of at least two separate grape domestication events: one in Transcaucasia and another one in Western Europe, possibly in Spain and Sardinia. More recently, De Michele et al. (2019) considered the hypothesis of a domestication centre and/or local introgression in Sicily, given the close relation between Sicilian wild populations and local cultivated germplasm. Scienza (2008) and Forni (2012) describe several centers of "accumulation", areas near ports located on major commercial routes, where many varieties were gathered over the centuries due to frequent and intensive contacts and interactions. Some of these areas have been identified as key centers of diversity. Distinct groups of cultivated grapevines were proposed by Negrul, who identified three proles: a proles pontica between Georgia and Asia Minor and in the Balkans, a proles occidentalis in Italy, France, the Iberian Peninsula, and Germany, and a proles orientalis in Central Asia, Persia, Armenia and Afganistan (Dalmasso, 1961). These groups match recent genetic evidence (eg. Bacilieri et al., 2013).

Riaz et al. (2018) suggest that cultivars from the proles pontica were introduced to Western Europe, because the wild grapes of Georgia - identified as an ancient centre of grapevine domestication - are closely related to Caucasian cultivated grapes (proles pontica) and the Western Mediterranean ones (proles occidentalis). 
Today, domesticated grape diversity is the result of millennia of human selection and diffusion. Ancient civilizations such as the Assyrians, Phoenicians, Greeks, Etruscans and Romans spread viticulture first across the Mediterranean basin, and later also into more temperate regions (McGovern, 2003). In the Western Mediterranean, there is an increasingly clear link between the Phoenician presence and the development of viticulture (Botto, 2013), as may be seen from both the archaeobotanical record (Buxó 2008; Pérez-Jordà et al., 2017; 2021; Ucchesu et al., 2015), and other elements in the archaeological record such as wine presses (Gómez Bellard et al., 1993) or evidence of trench agricultural systems (Vera Rodríguez and Echevarría Sánchez 2013). Evidence of Vitis vinifera in Phoenician sites is also found in association with animal bones (e.g. Moricca et al., 2020; Portas et al., 2015), as it is believed that the waste from winemaking was used by Phoenicians for meat preservation thanks to the antioxidant capacity of grapes (Sabato et al., 2019). Morphometry, the statistical analysis of form and its (co)variation (Rohlf and Bookstein, 1990), has played a key role in the study of grape pips from archaeological contexts since the early $20^{\text {th }}$ century to distinguish between wild and domesticated seeds (Stummer, 1911; Mangafa and Kotsakis, 1996). The approach was initially mainly based on measuring the length and breadth of the whole pip but it has developed to include multiple parameters, such as the length of the stalk or the position of the chalaza (Rivera Núñez et al., 2007); more recently, it has embraced geometric morphometrics and, in particular, outline analysis (Terral et al., 2010). Although only genetic analyses can demonstrate a direct connection between modern cultivars and archaeobotanical specimens (Guasch-Jané, 2019), geometric morphometric analyses are useful in archaeobotany, where shape is often the only remaining datum (Portillo et al., 2020). Since most of the surviving plant remains are usually seeds, outline analyses that do not require landmarks are particularly suitable and have been successfully used in numerous studies (eg. Ekhvaia and Akhalkatsi, 2010; Terral et al., 2010; Orrù et al., 2013; Ros et al., 2014; Pagnoux et al., 2015; Sabato et al., 2015a; Bonhomme et al., 2017; Bourgeon et al., 2018; Boso et al., 2020). Desiccated remains, whose shape was not modified by (sub)fossilization, have proven to be the most suitable material for morphometric analysis, followed by waterlogged ones (Bouby et al., 2013). An additional advantage that these categories carry is the possibility to perform DNA analyses, which can serve as a complementary tool (Bacilieri et al., 2017).

The study of charred grape pips is more challenging, as the (sub)fossilization results in a notable degree of deformation, in particular a swelling of the seed, which mostly occurs on the ventral side and which is best observed on the lateral outline (Smith and Jones, 1990; Bouby et al., 2018). This kind of deformation skews the identification of pips, moving them towards the wild morphotype. Despite the distortion of charred botanical remains, differences in seed shape may remain informative. Attempts to perform morphometric analyses on charred grape pips have been recently undertaken by Ucchesu et al. (2016) and Bouby et al. (2018), who both concluded that it is possible to distinguish between wild and domesticated pips, even if they are charred. Bouby et al. (2018) have moreover shown that if charring occurred at a temperature of $250^{\circ} \mathrm{C}$ or les, wild and domesticated pips may not only be correctly distinguished from each other, but it is also possible to identify correctly a high percentage of domesticated pips. Charring at higher temperatures 
increases the classification error, which means that cultivar classification may only use modern pips charred at lower temperatures and archaeological remains exposed to charring at low temperatures. Since it is hard to reconstruct the temperature that formed the archaeobotanical material, it is necessary to consider only large groups of very well preserved pips. In contrast, inflated specimens (indicative of higher temperatures) should only be considered for distinguishing wild from domesticated pips (Bouby et al., 2018). This paper compares, for the first time, grape pips collected from different sites with Phoenician connections to explore Phoenician interactions with plants and food and the role of commercial routes and trade goods. Were Phoenicians responsible for the spread of viticulture to the western Mediterranean? Or did they exploit and possibly domesticate wild grapes? Are modern cultivars a result of Phoenician influence?

\subsection{Study sites}

The present study focuses on the analysis of finds from three sites related to the Phoenician-Punic diaspora: Motya, Huelva and Nuraghe S'Urachi, which are respectively situated in Sicily (Italy), the Iberian Peninsula and Sardinia (Italy; Fig. 1). Motya was a Phoenician foundation, but both S'Urachi and Huelva were indigenous settlements already in existence before Phoenicians arrived in Sardinia and southern Spain.

Phoenicians and their material culture travelled the length and breadth of the Mediterranean in the first half of the $1^{\text {st }}$ millennium BC (Aubet Semmler, 2001; López-Ruiz and Doak, 2019). Their expansion from modern Lebanon towards the Western Mediterranean involved the major islands and many mainland coastal areas of the Mediterranean, such as Crete, Sicily, Sardinia, Andalusia and coastal North Africa. In all these areas, commercial and agricultural settlements were newly established or created in association with existing indigenous ones, and the relations between Phoenicians and local communities became a key aspect of the economic and social transformation of these regions.

While only Motya is a Phoenician foundation, all the three sites studied were nevertheless firmly associated with Phoenician expansion and cultural interaction.

Motya is a small island of about 45 ha situated in a sheltered lagoon on the Sicilian west coast, where it had offered an ideal "stop-over point" on trade routes into the West Mediterranean, including Sardinia, since the second millennium BC. The establishment of a permanent settlement in the $8^{\text {th }}$ century BC enabled the Phoenicians to consolidate their trade with the indigenous inhabitants of western Sicily (Nigro and Spagnoli, 2017; Nigro, 2018). The island had previously been inhabited by local Sicilian communities (Nigro, 2018).

Nuraghe S'Urachi is situated on the central west coast of Sardinia, on the northern shores of the Gulf of Oristano. The nuraghe itself was first built sometime in the Middle Bronze Age or mid- $2^{\text {nd }}$ millennium BC and remained continuously occupied well into the $1^{\text {st }}$ millennium BC. From around the turn of the $8^{\text {th }}-7^{\text {th }}$ century, Phoenician material culture was imported in increasingly abundant quantities and subsequently locally produced, suggesting a stable presence of Phoenicians (Stiglitz, 2007; van Dommelen et al., 2020). 
Situated in the coastal wetlands created by two rivers flowing into the Atlantic, the site of Huelva was likewise an indigenous settlement, where Phoenician material culture was imported as early as the $9^{\text {th }}$ century BC. It offered access to an important mining district in the interior, which enabled its inhabitants to establish connections across both the Atlantic and the Mediterranean (RuizGálvez Priego 1986; 2014). A small quantity of Sardinian pottery amidst a rich variety of Phoenician and other imports shows the involvement of both indigenous communities in Phoenician commercial networks Gonzales de Canales et al., 2006).

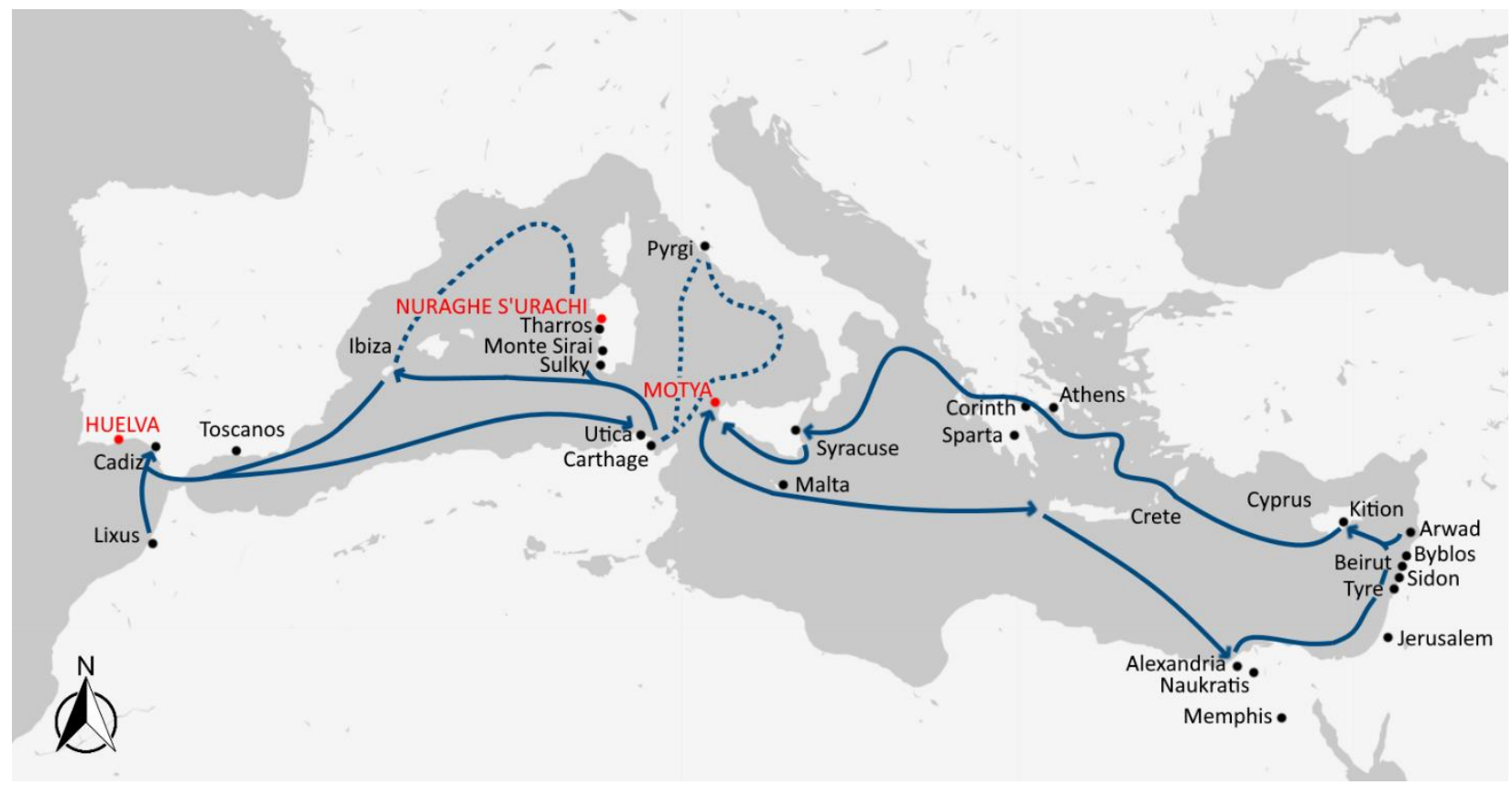

Figure 1. Map of the Mediterranean with the sites of Motya (37 $\left.52^{\prime} 05^{\prime \prime} \mathrm{N}, 12^{\circ} 28^{\prime} 10^{\prime \prime} \mathrm{E}\right)$, S'Urachi $\left(40^{\circ} 00^{\prime} 56^{\prime \prime} \mathrm{N}\right.$, $\left.8^{\circ} 34^{\prime} 57^{\prime} \mathrm{E}\right)$, and Huelva ( $\left.37^{\circ} 14^{\prime} 53^{\prime \prime} \mathrm{N}, 6^{\circ} 56^{\prime} 58^{\prime \prime} \mathrm{W}\right)$ along the Phoenician trade routes.

\section{Materials and Methods}

\subsection{Modern material}

Ten cultivars collected from the "Vivaio Federico Paulsen: Centro Regionale per la Conservazione della Biodiversità Agraria" in Marsala (TP, western Sicily) were selected as modern reference material (http://vivaiopaulsen.it). The choice of cultivars was based on their geographic origin, with three cultivars regarded as native to Georgia ("Chichvi", "Ogialesci" and "Zerdagi"), five to Sicily ("Albanello", "Catarratto", "Inzolia", "Perricone" and "Vitrarolo") and one to mainland Italy ("Coda di Volpe" - Tab. 1; Ansaldi et al., 2014, Galet, 2000). Sicilian varieties were chosen because they are assumed to be local, as they are attested in Sicilian writings since the $16^{\text {th }}$ century (Ansaldi et al., 2014). They may therefore be related to archaeological samples. The present study is moreover the first one to use a reference collection focused on Sicilian cultivars. The origin of "Zibibbo", also known as "Muscat of Alexandria", is debated. It has a long history of cultivation in Sicily, presumably starting with the Arabic domination of the Island (ca. $9^{\text {th }}$ century AD), even if it only first described as a cultivar in 1696 by Francesco Cupani (De Lorenzis et al., 2015). 
Although many cultivars have both black and white mutants (e.g. "Pinot"), we have maintained a balance in our sample between black and white grapes. 30 grape pips of each cultivar have been sampled for the present study, and each pip was given a unique identification code in order to compare its morphology before and after charring.

\begin{tabular}{lllll} 
Abbreviation & Cultivar & Origin & Berry color & Number of pips \\
\hline Alban & "Albanello" & Sicily & White & 30 \\
Catar & "Catarratto" & Sicily & White & 30 \\
Chicv & "Chichvi" & Georgia & White & 30 \\
Codad & "Coda di Volpe" & Italy & White & 30 \\
Inzol & "Inzolia" & Sicily & Black & 30 \\
Ogial & "Ogialesci" & Georgia & Black & 30 \\
Perri & "Perricone" & Sicily & Black & 30 \\
Vitra & "Vitrarolo" & Sicily & Black & 30 \\
Zerda & "Zerdagi" & Georgia & Black & 30 \\
Zibib & "Zibibbo" & Uncertain & White & 30
\end{tabular}

Table 1. Modern cultivars selected for the reference collection

\subsection{Charring conditions}

Experimental charring was performed on the selected pips in order to train identification models with pips representative of well-preserved archaeobotanical material. Charring conditions were established following the studies realized by Ucchesu et al. (2016) and Bouby et al. (2018), which evaluated the most suitable conditions of experimental charring for morphometric studies. They respectively defined temperature ranges of $240-310^{\circ} \mathrm{C}$ and $250-450^{\circ} \mathrm{C}$, below which charring resulted in heterogeneous carbonization and above which the pips disintegrated. Oxygen availability and duration of heating had a smaller impact on pip deformation, although it seemed slightly more accentuated under oxidizing conditions. Complete charring of the reference assemblages occurred already after 20 minutes. Bouby et al. (2018) concluded that only pips charred at a low temperature should be used for identification at the cultivar level, as charring at $250^{\circ} \mathrm{C}$ allowed not only to distinguish correctly between wild and domesticated pips, but also to identify accurately specific varieties.

Each of the selected pips, which had previously been given a unique identification code, was wrapped in two layers of aluminum foil in order to re-create reducing conditions, and to simulate the taphonomic factors which resulted in the creation of the archaeological assemblage. The pips were placed in a Thermolyne 48000 furnace at ambient temperature, the temperature was set at $250^{\circ} \mathrm{C}$ and the furnace was turned on. After 90 minutes the sample tray was removed from the oven.

\subsection{Archaeological material}


Archaeological grape pips were collected from the western Mediterranean sites of Motya, Nuraghe S'Urachi and Huelva. The archaeological material from Motya consisted of 189 grape pips deriving from an $8^{\text {th }}-6^{\text {th }}$ century $\mathrm{BC}$ refuse pit, which had been preserved by carbonization and retrieved using the bucket floatation technique. The grape seeds come from six stratigraphic units interpreted as four depositional events (Table 2; Moricca et al., 2021). Few pedicels were found compared to the number of grape seeds. This is coherent with wine-making refuse as studied by Margaritis and Jones (2006).

\begin{tabular}{lll}
$\begin{array}{l}\text { Filling layer } \\
(\text { FL) }\end{array}$ & Stratigraphic unit (US) & Chronology \\
\hline I-III & 1112 & End of $7^{\text {th }}-$ mid $6^{\text {th }}$ century BC \\
& 2268 & \\
IV & 1406 & Mid- $7^{\text {th }}$ century BC \\
& 1407 & \\
V & 1492 & End of $8^{\text {th }}-$ first half of the $7^{\text {th }}$ century BC \\
VI & 7234 & Mid-second half of the $8^{\text {th }}$ century BC
\end{tabular}

The material from the sites of S'Urachi and Huelva was by contrast preserved by waterlogging. The 179 grape pips from S'Urachi come from the fill of a trench that was backfilled with rubbish from the early $7^{\text {th }}$ century BC onwards, along with other fruits, cereals as well as large quantities of animal bones and pottery (Pérez-Jordà et al., 2020). dumped in a port area. The sediment was extracted mechanically but associated radiometric dates and archaeological evidence allow us to place it in the $9^{\text {th }}-8^{\text {th }}$ century BC (Pérez-Jordà et al., 2017).

\subsection{Morphometric analysis}

Modern (both pre- and post-charring) and archaeological grape pips were positioned on a blue background and photographed in dorsal and lateral position (Fig. 2) at a fixed magnification using an Olympus SZ-ET stereomicroscope and an Olympus DP 12 camera. These images were processed in order to obtain black masks on a white surface. Outlines coordinates (x; y) were extracted and 360 points, equally spaced along the curvilinear abscissa were sampled. Normalization of the outlines was carried out by centering, aligning them along their longest axis, scaling them using their centroid size, and by defining the first point right above the centroid (Bouby et al., 2018). Elliptic Fourier transform (EFT) approach (Kuhl and Giardina, 1982) subsequently enabled us to turn the shape into multivariate coefficients. EFT involves the decomposition of $\mathrm{x}$ - and $\mathrm{y}$ - coordinates as two harmonic sums of trigonometric functions (Bonhomme et al., 2014). The two views were treated separately, and their coefficients were later combined. In our case, seven harmonics were chosen for the two views, enough to gather $99 \%$ of the total harmonic power. Each harmonic corresponds to four coefficients, so EFT resulted in 56 coefficients ( 2 views $\times 7$ harmonics $\times 4$ coefficients per harmonic), which weretreated as 
quantitative variables. The Momocs package (Bonhomme et al., 2014; version 1.3.2 available at https://github.com/MomX/Momocs) was used for morphometric analysis. All analyses were performed in the R environment, version 4.0.2 (R Core Team, 2020).



Figure 2. Pip \#4 from stratigraphic unit US 1492 (Motya) in dorsal and lateral views.

\subsection{Statistical analyses}

276

277

278

To begin with, shape variability of the modern charred and uncharred pips and the archaeological seeds were assessed and compared at different levels using Principal Component Analyses (PCA). Preliminary analyses were conducted to quantify any error related to the positioning of pips for photographic documentation and their graphical elaboration. A PCAgeo (Fig. 3) on the matrices of the EFT coefficients of modern uncharred pips was first calculated to characterize seed shape variability at the cultivar level. A mean score was drawn up for each variety. The first two principal components (PC 1 and PC 2) are shown in Figure 3, along with the corresponding morphological space that illustrates the shape components captured by these PCs. Secondly, charred samples were



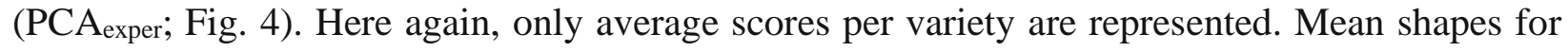
modern pips were also calculated to visualize these changes (Fig. 5).

Regarding the archaeological pips, a $\mathrm{PCA}_{\text {archeo }}$ (Fig. 6) was carried out in order to compare the pips from the sites of Motya, Nuraghe S'Urachi and Huelva. We used the first 12 PCs, that gather $95 \%$ of the total variance to test for differences between assemblages using a permutational MANOVA as implemented in the package 'vegan' (Oksanen et al., 2019). We then carried out two PCAs (PCA water $_{\text {and PCA }}$ char; Fig. 7 and 8) on modern material (uncharred and charred). The waterlogged 
292 (Huelva and S'Urachi) and charred (Motya) archaeological pips were reprojected on these PCAs 293 as additional observations.

\section{Results}

296 The first two principal components (PCs) of the PCA performed on uncharred modern samples 297 (PCAgeo) explain 59.2\% of the total variance (Fig. 3). PC1 (38.2\%) distinguishes between roundish 298 pips with a short stalk, characterizing shapes close to the wild morphotype, and more elongated 299 pips with a longer stalk, typically associated with cultivated grapes. PC2 (21.0\%) mostly captures the straightness/curviness of the pip outline in lateral view.

\subsection{Provenance of cultivars}

302 The application of PCAgeo to modern materials makes it possible to highlight the differences in 303 seed shape between cultivars, which can be compared to the geographical origin of each cultivar 304 (Fig. 3).

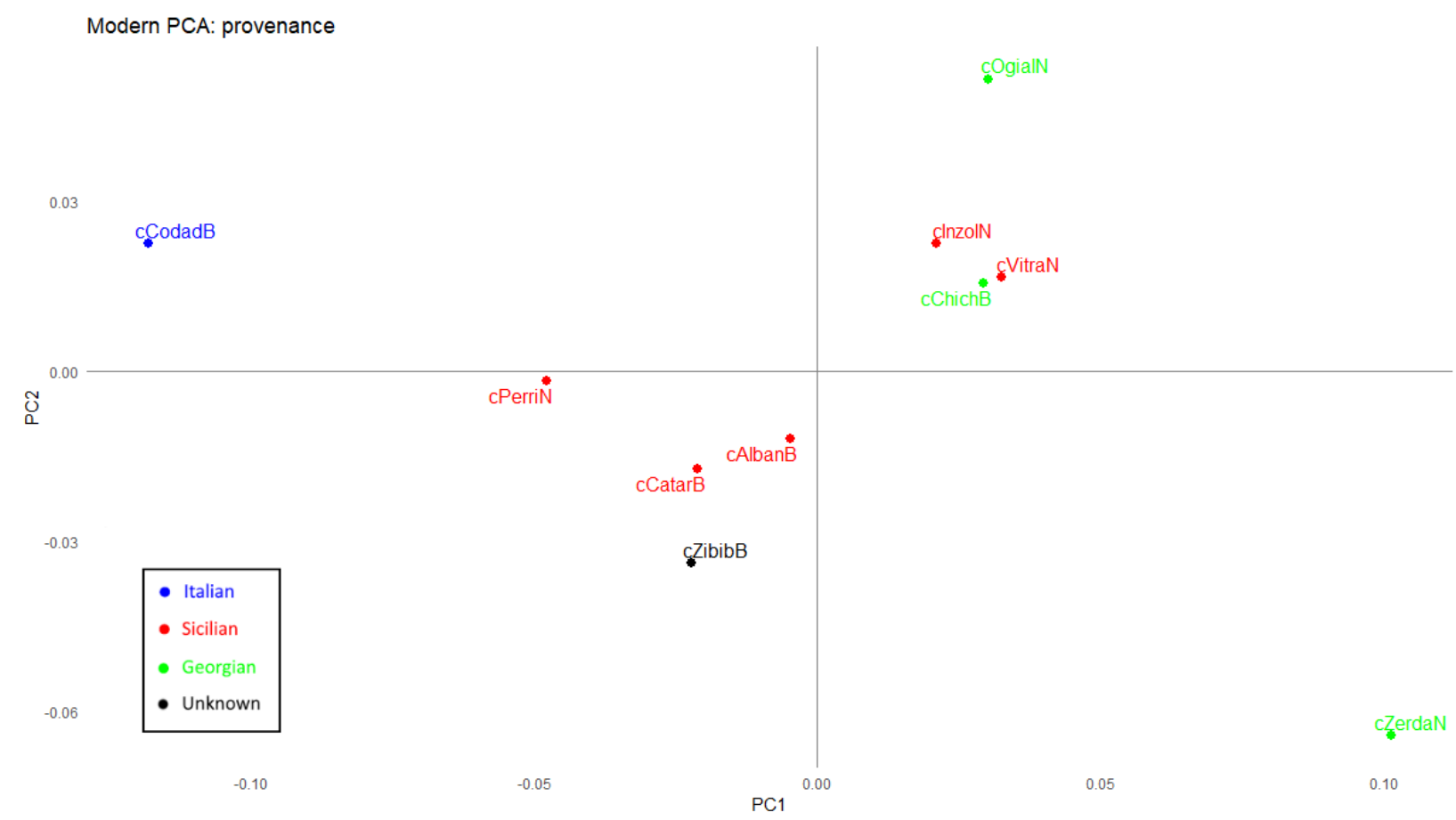

Figure 3. PCA on reference cultivars in association with their geographical origin (PCA geo).

The center of the plot is occupied by the Sicilian cultivars, while the Georgian ones are shifted towards the righthand side of the graph. Pips of the Georgian cultivars are broader and more laterally curved than the Sicilian ones, which present a shape closer to that of wild plants. "Coda 
311 di Volpe", which is the only cultivar from the Italian mainland in the analysis, presents by contrast 312 pips that are on average more elongated and straighter in the lateral outline.

313

314

315

316

317

318

319

320

321

322

323

324

325

326

327

328

329

330

331

332

333

\subsection{Charring effect}

PCA on reference materials has enabled us to describe the effects of experimental charring in terms of changes in pip shape (PCA exper; Fig. 4). This is reflected in a general inflation of the pip bodies, resulting in an overall plumpness (PC1) and a straightening of the lateral outline (PC2). All cultivars follow a similar pattern. The calculated mean shapes associated with the charring conditions (Fig. 5) show that charring mostly affects the lateral section, particularly on the ventral side with an inflation of the body and a change in inclination of the beak. The changes in the dorsal view are nevertheless much lower.

\section{(a)}

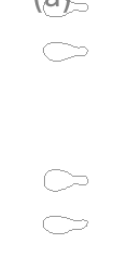

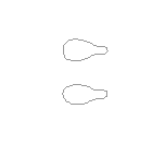
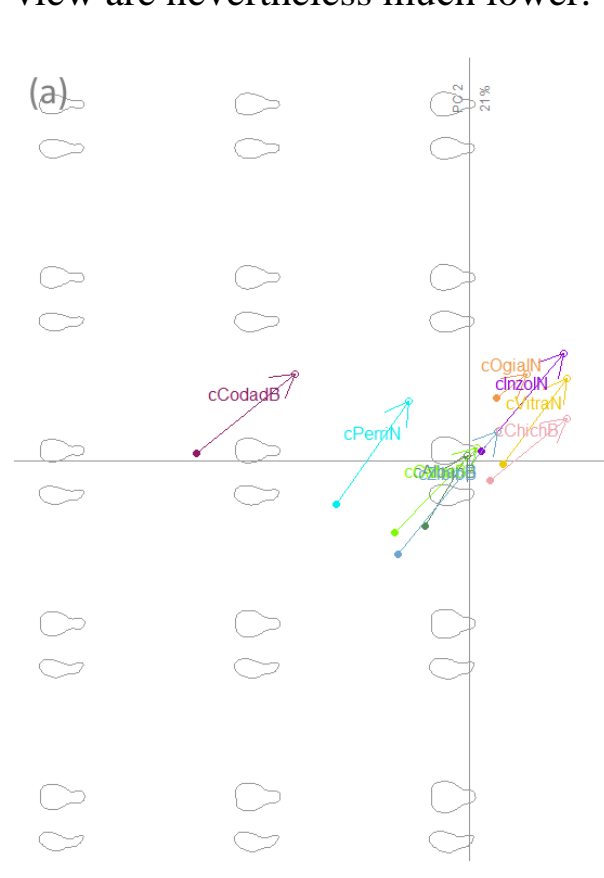

Figure 4. The effects of charring on modern cultivars: a) PCA describing the effects of charring on modern cultivars $\left(\mathrm{PCA}_{\text {exper }}\right)$; b) mean shapes of all pips, Chichvi pips and Zerdagi, dorsal (left) and lateral (right) outlines. Blue line for uncharred pips, red for charred ones. 
while pips from the Motya deposit have a straighter lateral outline. This is coherent with the results of the previous analyses, as PC2 is mostly explained by charring. Pips from Huelva and Motya's US 1407 are very similar, as they are the most elongated ones among the studied pips; they also have a similar curvature in the lateral outline. While looking specifically at the waterlogged assemblages, it is possible to see that pips from S'Urachi are the broadest. This analysis does not, however, take into consideration the effect of charring, which our experiments have shown to cause an inflation of the pip body.

Arch PCA

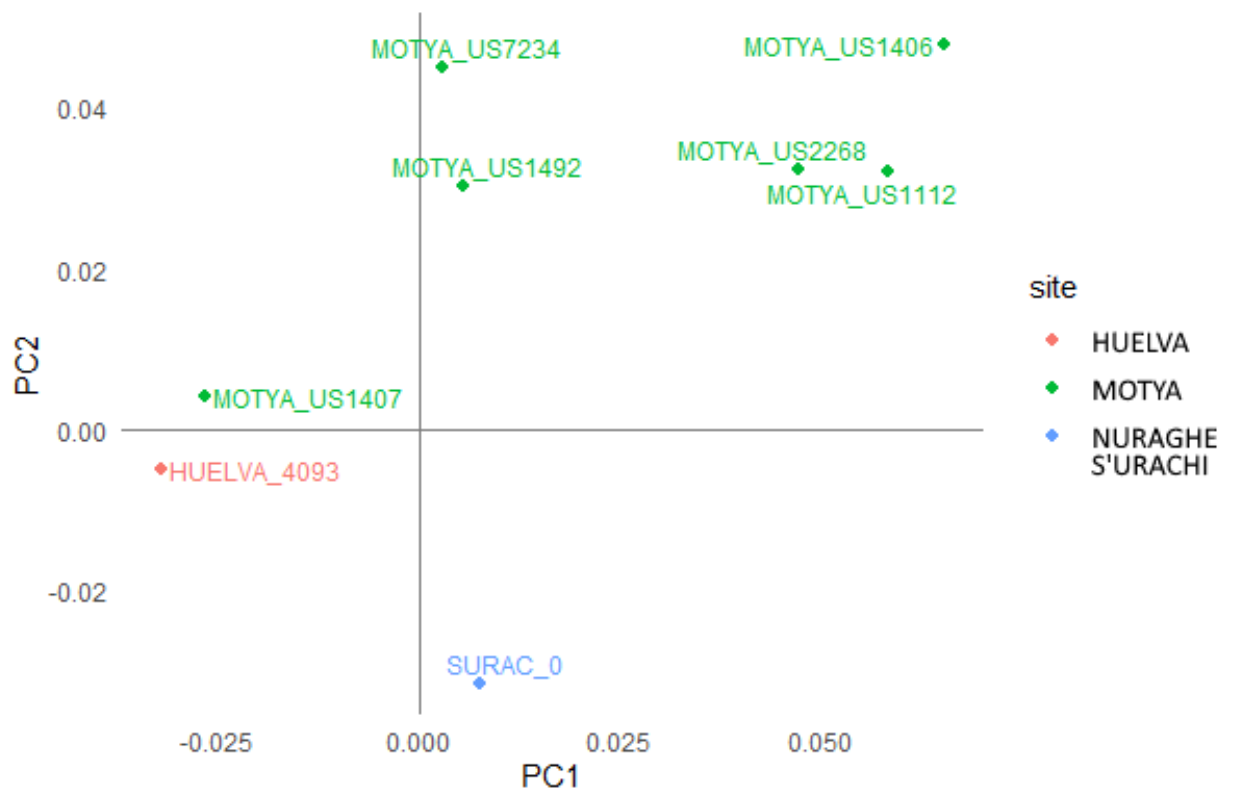

Figure 5. PCA of archaeological samples ( $\left.\mathrm{PCA}_{\text {archeo }}\right)$.

For this reason, separate PCA analyses were also performed on the waterlogged (Supplementary Material 1) and charred archaeological pips (Supplementary Material 2). These analyses showed results coherent with those obtained in $\mathrm{PCA}_{\text {archeo. }}$

Archaeological waterlogged samples were later projected on PCAgeo, previously obtained for

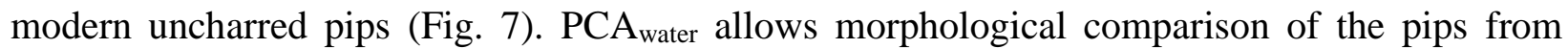
Huelva and S'Urachi with modern cultivars. Although the pips from S'Urachi are closest to those of "Albanello", they do not match the modern cultivars. This is also the case with the ones from Huelva.

The permutational MANOVA carried out to test differences between assemblages was comprised of a pairwise comparison of modern varieties (both charred and uncharred) and archaeological samples. In pairwise comparisons, p-values lower than 0.05 , which indicate differences in the pairwise comparison, were seen for: "Albanello" and Huelva; "Coda di Volpe" and Motya US2268; "Ogialesci", S’Urachi and Motya US1407; "Perricone”, Motya US1407 and US2268; “Zerdagi”, Motya US1492 and US2268. 
Finally, average scores for samples from Motya were plotted on the PCA previously obtained for the experimentally charred modern cultivars (Fig. 8). This shows that the samples from Motya are relatively distant from modern cultivars. Even so, the pips from US 1407 and US 7234 are most similar to "Perricone", while the mean score for US 1492 falls between "Perricone" and "Catarratto", US 2268 is closest to "Zibibbo", and the pips from US 1112 and US 1406 are finally closest to "Chichvi".

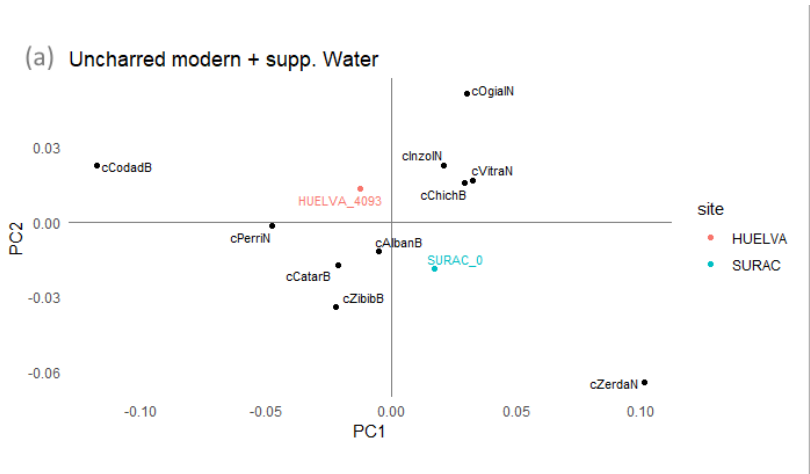

Figure 6. a) PCA of waterlogged archaeological seeds and modern uncharred cultivars ( $\left.\mathrm{PCA}_{\text {water }}\right)$; b)PCA of charred

grape pips from Motya and modern reference cultivars experimentally charred (PCA $\mathrm{P}_{\text {char }}$ ).



\section{Discussion}

The present study represents a first attempt to evaluate differences in assemblages of grape pips from Phoenician sites and sites that underwent Phoenician influence. Here we show that: a) there is a correlation between the geographical origin of modern cultivars and the shape of their pips; b) the results of the charring experiments are coherent with the existing literature; c) a comparison between modern and archaeological pips allows the identification of the sites with the most and least "domesticated" pips; d) no direct match with modern cultivars has been found, even if some similarities may be noted.

In the first place, we have found a correlation between the pip shape of modern cultivars with their geographical origin, despite a slight overlap of the Sicilian and the Georgian clusters. This correlation has previously been observed, just as it has also been noted that considering a higher number of varieties results in less clear-cut differences between geographical groups (Pagnoux et al., 2015).

The results concerning the deformation of pips by charring are consistent with the experiments conducted by Smith and Jones (1990) and Bouby et al. (2018) and show that the grapevine seeds become rounder when charred. The stalk is less affected by deformations, at least in its length. Charring also affects the lateral side by decreasing its curvature.

$\mathrm{PCA}_{\text {archeo }}$ carried out on archaeological pips allows a first comparison of their morphology. Although slight differences were seen in the roundness of the pips, with those from Huelva and Motya's US 1407 being the slimmest, and those from three stratigraphic units in Motya being the 
roundest, most differences concerned the straightness of the lateral outline and may be ascribed to charring.

A more appropriate comparison of archaeobotanical samples was carried out indirectly, by projecting waterlogged pips on $\mathrm{PCA}_{\text {geo }}$ and charred ones on $\mathrm{PCA}_{\text {exper. }}$.

The comparison between waterlogged seeds from Huelva and S'Urachi highlighted differences rather than similarities. On average, pips from the former site were slimmer and their lateral outline was less curved, in comparison to the ones coming from the Sardinian excavation. At the site of Sa Osa, which is only $10 \mathrm{~km}$ from S'Urachi, Vitis vinifera remains were found in levels dating to the $13^{\text {th }}$ century BC (Orrù et al., 2013), suggesting an earlier tradition of vine cultivation. This could have been maintained on the island in the following centuries, as suggested by the high concentrations of Vitis pollen in the adjacent Mistras lagoon between the middle Bronze Age and the Punic Period (approx. from 3500 to $2500 \mathrm{cal} \mathrm{BP;}$ Di Rita and Melis, 2013). In contrast, in the Huelva area grape pips are not present before the $9^{\text {th }}-8^{\text {th }}$ centuries. Comparison with modern varieties is not as straightforward. Even if pips from S'Urachi share some features with the modern ones of "Albanello", "Chichvi", "Vitrarolo" and "Zibibbo" grapes, no clear correspondence is evident. Even if this lack of conformity may be due to the limited size of the reference collection, we should consider that these are modern varieties, that were quite likely introduced later in history. How closely related can modern and ancient varieties be in a given region? Since grapevines are commonly managed through vegetative propagation it is possible for varieties to remain genetically unchanged for centuries. Nonetheless, new cultivars can be created through sexual crosses or somatic mutations. Ancient DNA studies that may help to trace kinship with modern varieties have been undertaken on archaeological pips from several archaeological sites in France (Ramos-Madrigal et al., 2019). Although a clear match ("Savagnin blanc") was only found at a medieval site, several pips from Roman sites show first-degree relationships with modern French and Swiss cultivars. This suggests that at least some varieties may remain virtually unchanged since Roman times, and possibly for a longer time.

Misidentification can, nonetheless, be influenced by taphonomic factors, including the fact that remains may become slightly swollen because of waterlogging (Pagnoux et al., 2015).

The samples from Motya, which have been preserved through charring, differ mostly by their roundness. Pips from the most recent stratigraphic units (US 1112 and US 2268), which make up a single filling layer (Table 2), are the wider ones, with their shape appearing to be of a "least domesticated" type. The expression "least domesticated" refers to the morphology, describing the rounder pips with shortest stalk, closest to the wild morphotype. Similarly, the "most domesticated" pips are the most elongated ones with long stalks. The presence of different morphologies within one filling layer may be related to the fact that these stratigraphic units also included materials from pre-Phoenician layers (such as pottery and other objects), dated back to the $16^{\text {th }}-13^{\text {th }}$ century BC. The "least domesticated" pips could therefore have been deposited along with the latter. Pips of units 1407, 1492 and 7234 seem by contrast more elongated and with longer stalks. It is surprising, therefore, that pips from stratigraphic units 1406 and 1407, which also belong to the same depositional layer, differ quite substantially in shape. This may however be due 
to the small sample size obtained from US 1407. There exists in fact overlap between the datasets, if we examine the values obtained for single pips. The differences may be explained by the presence of different grape varieties within the same depositional layer. A second explanation could be uneven charring in the archaeological context. The context of retrieval is a disposal pit that is several meters wide (Moricca et al., 2021). This would allow for the possibility that higher temperatures were achieved in US 1406 than US 1407, found on the opposite sides of the same filling layer. Charring at higher temperatures has been proven to cause an inflation of the pip bodies (Bouby et al., 2018). Nonetheless, this explanation seems less likely. Such reasoning may also apply to the samples from US 1112 and 2268, even if the values are not as contrasting. In terms of their correspondence to modern cultivars, the outlines of pips from units 1112 and 1406 best resemble pips from "Chichvi" grapes, while the seeds from the other samples present shapes noticeably different from the modern reference cultivars. It is interesting in this regard to consider the results of the genetic study carried out by Riaz et al. (2018), who analyzed 1378 cultivated and wild grape samples collected around the Mediterranean basin and Central Asia. While most Italian cultivars clustered with those from France, Spain and Pakistan - Turkmenistan, a small subset was associated with wild and cultivated grapevines from Georgia. This suggests that the first domesticated cultivars in Central Asia and Caucasus (the proles pontica) somehow did leave a genetic footprint in the Western European proles occidentalis.

"Zerdagi" is the modern variety with the broader seeds and least elongated stalks, and which is therefore most like wild grapes, but there are no subfossil equivalents in either the waterlogged or charred assemblages. The same holds for the "Coda di Volpe" variety, which has the slimmest pips and the shortest stalks. These observations may suggest a certain level of domestication of the vine from all the sites studied.

Although this reference collection is smaller than those used in other morphometric studies of archaeological grape pips (e.g. Bouby et al., 2021; Pagnoux et al. 2015; Bonhomme et al., 2021), it still encompasses the previously observed archaeological variability.

The results of $\mathrm{PCA}_{\text {water }}$ and $\mathrm{PCA}_{\text {char }}$ suggest that archaeological material from the three sites is, morphologically, broadly comparable to the modern varieties, which similarly suggests that the archaeological finds represent, broadly speaking, domesticated grapes. If we take into consideration the effects of charring, we note that the "slimmest" pips come from three stratigraphic units at Motya, which may suggest the presence, or perhaps cultivation, of "more strongly domesticated" varieties at or near the Sicilian site.

A diversity of cultivated grapes can be observed in the studied sites. This may be ascribed to local adaptation, one hypothesis could be introgression with local grapevines, as suggested by Forni (2012). Another option to consider is that the pips of Motya could be related to the proles pontica, which is believed to have left a genetic footprint in the proles occidentalis in the Western Mediterranean (Riaz et al., 2018). This might explain differences between the samples from Motya and those from the indigenous sites of S'Urachi and Huelva.

Sicilian viticulture is structured by a group of varieties of regional interest, and a bigger group of minor varieties present with a certain frequency only in specific viticultural areas or at the level of 
a few strains. The latter are referred to as "reliquia" and include "Inzolia" and "Vitrarolo" (Scienza and Failla, 2016). Genetic studies have identified the variety "Sangiovese", as the progenitor of numerous Sicilian cultivars, amongst which "Perricone". Furthermore, multivariate statistical analyses carried out on 11 SSR loci of 46 Sicilian varieties have shown a clear distinction between varieties based on their geographical origin, with Eastern Sicilian cultivars ("Nerello mascalese", "Nerello cappuccino", "Frappato", "Perricone" and "Carricante") clustering on one side, and those typical of western Sicily ("Inzolia", "Catarratto", "Grecanico", "Nero d'Avola") on the other (De Lorenzis et al., 2014).

A correspondence between our morphometric results and the ampelographic history of Sicily is not straightforward, either. Even so, pips from S'Urachi find morphological similarities with those of "Albanello", while three samples from Motya are plotted in the space between "Catarratto" and "Perricone". It is however unclear how we may interpret such associations.

The substantial intra-site diversity in pip morphology at Motya should also be noted, as the sample would seem to cover a range of different varieties. Taphonomic factors, such as differential charring, may however have affected pip morphology. At all the sites the morphology of the pips suggests fully domesticated grapes. The clear differences between pip morphology at the three sites goes against the idea that Phoenicians favoured the spread of grape varieties. It appears more likely that their viticulture was based on local grape varieties, and thus varied with the sites where they settled.

The first evidence of viticulture in the Central and Western Mediterranean comes from Northern Italy (Cremaschi et al., 2016; Pecci et al., 2020) and Sardinia (Sabato et al., 2015) and has been dated to the Middle and Late Bronze Age (ca. 1650-930 BC). It does not, however, point to the exclusive use of domesticated varieties. There is little or no evidence to assess the continuity, scale and prominence of viticulture in the western Mediterranean during the later $2^{\text {nd }}$ millennium $\mathrm{BC}$, but that changes by the beginning of the $1^{\text {st }}$ millennium with new finds from Tunisia, Sicily, Sardinia and the Iberian Peninsula, which may be associated with a Phoenician presence. The rapid growth of vine cultivation and wine production in the first half of the new millennium generated increasingly frequent exchanges of wine amphorae across the Western Mediterranean (Botto, 2013). Vine cultivation and wine production also became widespread in indigenous areas, where amphora production and wine presses have been found (Pérez-Jordà et al., 2013). Thanks to the Orientalizing influence, which includes not only Phoenicians, but also Greeks and Etruscans, wine soon became a very successful and widely distributed product with substantial agricultural, economic and cultural impact and significance (Botto, 2013). This underscores the interest of trying to define in precise terms the history, distribution, expansion and cultural appreciation of this crop. The varieties that were introduced and/or created in each of the areas are an essential element of this historical process, which indicates the relevance of the line of research that is opened with this work.

\section{Conclusions}


The present study has first of all allowed us to characterize the pip morphology of grapes cultivated by Phoenicians and connected indigenous communities in the West Mediterranean and to assess the similarities and difference between these ancient seeds and modern varieties using geometric morphometry.We first of all observed that all the studied archaeological grape pip samples fall within the range defined by the modern cultivars, which is reason to describe our archaeological samples as 'domesticated-looking'. Taking in consideration the effects of charring on pip shape, pips from three stratigraphic units at Motya (1407, 1492 and 1407) appear to be the slimmest. More specifically, pips from stratigraphic unit 1407 are the most elongated, closely followed by those from units 1492 and 7234. Although it was not possible to associate them with any specific modern variety, they broadly resemble the Sicilian cultivars "Perricone" and "Catarratto". In terms of elongation, these are closely followed by pips from Huelva, which do not resemble any of the reference cultivars. The remaining pips from S'Urachi and Motya (US 2268, 1406 and 1112) are rounder.

None of the pips investigated resembles those of the Georgian cultivar "Zerdagi", which has the roundest pips amongst the selected modern cultivars.

The key challenge for the present study was the comparison of archaeological pips preserved through different fossilization processes (waterlogging and charring). Although it is impossible to undo the charring conditions that created the archaeobotanical assemblage, experimental charring has been used to obtain material that may be compared to well-preserved archaeobotanical material. The use of two reference datasets of the same modern cultivars, one uncharred and one charred, has enabled us to tackle the complications of differential preservation.

Our analysis represents a first step towards a better understanding of diachronic and synchronic relationship between vines grown in the ancient West Mediterranean. We are well aware that the small number of reference cultivars used in this study may not adequately represent the diversity of modern grapevine cultivars. Even so, our selection still offers a general impression of modern similarities with the archaeological samples, which supports our suggestion that local cultivation and selection could have produced important changes and long-term consequences.

We recommend that future studies be carried out with a larger number of modern reference cultivars that better represent contemporary biological diversity. An additional focus could be placed on modern Sardinian and Iberian cultivars. If the number of samples from each archaeological site could also be increased, we would also gain a better understanding of grape diversity at each site. Even so, finds from other sites would likely be necessary to take a broader view and to evaluate the role of Phoenicians in the diffusion of the grapevine across the western Mediterranean.

\section{Acknowledgements}

The plant material from Motya was recovered by the Sapienza Archaeological Expedition to Motya thanks to the fruitful cooperation with the Soprintendenza Archeologica of Trapani of the Sicilian Region, and the G. Whitaker Foundation, Palermo. The botanical remains from S'Urachi were collected as part of the ongoing excavations of the S'Urachi Project, with permission of the 
Italian Culture Ministry (MIBACT) and the collaboration of the Comune of San Vero Milis (OR, Sardinia).

The authors would like to thank Alberto Parrinello from the "Vivaio Federico Paulsen - Centro Regionale per la Conservazione della Biodiversità Agraria” in Marsala (Sicily) for providing modern reference material. We also gratefully acknowledge Thierry Pastor's assistance with the photographic acquisition of modern cultivars.

\section{Funding}

This work is a product of the PRIN 2017 Project: "People of the Middle Sea. Innovation and integration in ancient Mediterranean (1600-500 BC)" [A.3 Flora antiqua; 2017EYZ727]. It benefited from support from the Viniculture [ANR-16-CE27-0013] and FRUITCOM [CIDEGENT/2019/003] projects. This research was possible thanks to a $\mathrm{PhD}$ grant of the Department of Earth Sciences, Sapienza University of Rome.

\section{Bibliography}

Ansaldi, G., Cartabellotta, D., Falco, V., Gagliano, F., Scienza, A. 2014. [Identity and richness of the Sicilian vineyard] Identità e ricchezza del vigneto Sicilia. Regione Siciliana, Assessorato dell'Agricoltura, dello Sviluppo Rurale e della Pesca Mediterranea, Palermo. Italian.

Arroyo-García, R., Ruiz-Garcia, L., Bolling, L., Ocete, R., Lopez, M.A., Arnold, C., Ergul, A., Söylemezoglu, G., Uzun, H.I., Cabello, F., Ibáñez, J., Aradhya, M.K., Atanassov, A., Atanassov, I., Balint, S., Cenis, J.L., Costantini, L., Gorislavets, S., Grando, M.S., Klein, B.Y., Mcgovern, P.E., Merdinoglu, D., Pejic, I., Pelsy, F., Primikirios, N., Risovannaya, V., Roubelakis-Angelakis, K.A., Snoussi, H., Sotiri, P., Tamhankar, S., This, P., Troshin, L., Malpica, J.M., Lefort, F., Ibanez, J., 2006. Multiple origins of cultivated grapevine (Vitis vinifera L. ssp. sativa) based on chloroplast DNA polymorphisms. Mol. Ecol. 15(12), 3707-3714. doi.org/10.1111/j.1365-294X.2006.03049.x

Aubet Semmler, M.E., 2001. The Phoenicians and the West: Politics, Colonies and Trade. Cambridge University Press, Cambridge.

Bacchetta, G., Farci, M., Grillo, O., Lovicu, G., Orrù, M., Venora, G. 2009. Image analysis a new tool for pips morpho-colorimetric measurements of the Sardinian landraces of Vitis vinifera L. subsp. vinifera. Proceedings of the 45th international congress of SISV \& FIP, 22-24.

Bacilieri, R., Bouby, L., Figueiral, I., Schaal, C., Terral, J.F., Breton, C., Picq, S., Weber, A., Schlumbaum, A. 2017. Potential of combining morphometry and ancient DNA information to investigate grapevine domestication. Veg. Hist. Archaeobot. 26(3), 345-356. doi.org/10.1007/s00334-016-0597-4 
Bacilieri, R., Lacombe, T., Le Cunff, L., Di Vecchi-Staraz, M., Laucou, V., Genna, B., ... \& Boursiquot, J. M. 2013. Genetic structure in cultivated grapevines is linked to geography and human selection. BMC Plant Biol. 13(1), 1-14.

Bonhomme, V., Forster, E., Wallace, M., Stillman, E., Charles, M., Jones, G. 2017. Identification of inter-and intra-species variation in cereal grains through geometric morphometric analysis, and its resilience under experimental charring. J. Archaeol. Sci. 86, 60-67. doi.org/10.1016/j.jas.2017.09.010

Bonhomme, V., Picq, S., Gaucherel, C., Claude, J. 2014. Momocs: Outline Analysis Using R. J. Stat. Softw. 56(13), 1-24.

Bonhomme, V., Terral, J. F., Zech-Matterne, V., Ivorra, S., Lacombe, T., Deborde, G., ... \& Bouby, L. (2021). Seed morphology uncovers 1500 years of vine agrobiodiversity before the advent of the Champagne wine. Sci. Rep. 11(1), 1-14.

Boso, S., Gago, P., Santiago, J.L., Teira-Brión, A., Martín-Seijo, M., Rey-Castiñeira, J., Ocete, R., Ocete, C., Martínez, M.C. 2020. Morphometric comparison of current, Roman-era and medieval Vitis seeds from the north-west of Spain. Aust. J. Grape Wine Res. 26(3), 300-309. doi.org/10.1111/ajgw.12439

Botto, M. 2013. The Phoenicians and the spread of wine in the central West Mediterranean, in: Celestino Pérez s., Blánquez Pérez, J. (Eds.), Patrimonio cultural de la vid y el vino: conferencia internacional. UAM Ediciones, Madrid, 103-31.

Bouby, L., Figueiral, I., Bouchette, A., Rovira, N., Ivorra, S., Lacombe, T., ... \& Terral, J.F. 2013. Bioarchaeological insights into the process of domestication of grapevine (Vitis vinifera L.) during Roman times in Southern France. PLoS One. 8(5), e63195. doi.org/10.1371/journal.pone.0063195

Bouby, L., Bonhomme, V., Ivorra, S., Pastor, T., Rovira, N., Tillier, M., Pastor, T., Picq, S., Marinval, P., Terral, J.F. 2018. Back from burn out: are experimentally charred grapevine pips too distorted to be characterized using morphometrics?. Archaeol. Anthrop. Sci. 10(4), 943-954. doi.org/10.1007/s12520-016-0425-X

Bouby, L., Wales, N., Jalabadze, M., Rusishvili, N., Bonhomme, V., Ramos-Madrigal, J., ... \& Maghradze, D. 2021. Tracking the history of grapevine cultivation in Georgia by combining geometric morphometrics and ancient DNA. Vegetation History and Archaeobotany, 30(1), 6376.

Bouby, L., \& Ruas, M. (2014). Adding diversity. Between occasional food and speculative productions: Diversity of fruit uses, diversity of practices regarding fruit tree cultivation (Introduction). In A. Chevalier, E. Marinova, \& L. Peña-Chocarro (Eds.). Plants and People. Choices and diversity through time (Vol. 1, Early Agricultural Remnants and Technical Heritage (EARTH): 8,00 years of Resilience and Innovation, pp. 141-149). Oxford: Oxbow Books. 
614 Bourgeon, O., Pagnoux, C., Mauné, S., Vargas, E.G., Ivorra, S., Bonhomme, V., Ater, M., 615 Moukhli, A., Terral, J.F. 2018. Olive tree varieties cultivated for the great Baetican oil trade 616 between the 1st and the 4th centuries AD: morphometric analysis of olive stones from Las Delicias 617 (Ecija, Province of Seville, Spain). Veg. Hist. Archaeobot. 27(3), 463-476. 618 doi.org/10.1007/s00334-017-0648-5

619 Buxó, R. 2008. The agricultural consequences of colonial contacts on the Iberian Peninsula in the 620 first millennium B.C. Veg. Hist. Archaeobot. 17, 145-154. doi.org/10.1007/s00334-007-0133-7

621 Cremaschi, M., Mercuri, A. M., Torri, P., Florenzano, A., Pizzi, C., Marchesini, M., \& Zerboni, 622 A. 2016. Climate change versus land management in the Po Plain (Northern Italy) during the 623 Bronze Age: New insights from the VP/VG sequence of the Terramara Santa Rosa di 624 Poviglio. Quaternary Sci. Rev. 136, 153-172.

625 Dalmasso, G. 1961. Vite. Enciclopedia Italiana. http://www.treccani.it/enciclopedia/vite_res$626 \quad 11304 \mathrm{~d} 2 \mathrm{~b}-87 \mathrm{e} 9-11 \mathrm{dc}-8 \mathrm{e} 9 \mathrm{~d}-0016357$ eee51_\%28Enciclopedia-Italiana\%29/ (accessed 15 May 627 2020).

628 De Lorenzis, G., Squadrito, M., Brancadoro, L., Scienza, A. 2015. Zibibbo Nero characterization, 629 a red-wine grape revertant of Muscat of Alexandria. Mol. Biotechnol. 57(3), 265-274. 630 doi.org/10.1007/s12033-014-9820-7

631 De Lorenzis, G., Las Casas, G., Brancadoro, L., Scienza, A. 2014. Genotyping of Sicilian 632 grapevine germplasm resources ( V. vinifera L.) and their relationships with Sangiovese. Sci. 633 Hortic. 169, 189-198. doi.org/10.1016/j.scienta.2014.02.028

634 De Michele, R., La Bella, F., Gristina, A. S., Fontana, I., Pacifico, D., Garfi, G., ... \& Carimi, F. 635 (2019). Phylogenetic relationship among wild and cultivated grapevine in Sicily: a hotspot in the 636 middle of the Mediterranean Basin. Front. Plant Sci. 10, 1506. doi.org/10.3389/fpls.2020.01176

637 Di Rita, F., Melis, R.T. 2013. The cultural landscape near the ancient city of Tharros (central West 638 Sardinia): vegetation changes and human impact. J. Archaeol. Sci. 40(12), 4271-4282.

639 Ekhvaia, J., Akhalkatsi, M. 2010. Morphological variation and relationships of Georgian 640 populations of Vitis vinifera L. subsp. sylvestris (CC Gmel.) Hegi. Flora Morphol. Distribut. Funct. 641 Ecol. Plants. 205(9), 608-617. doi.org/10.1016/j.flora.2009.08.002

642 Figueiral, I., Bouby, L., Buffat, L., Petitot, H., Terral, J.F. 2010. Archaeobotany, vine growing and 643 wine producing in Roman Southern France: the site of Gasquinoy (Béziers, Hérault). J. Archaeol. 644 Sci. 37(1), 139-149. doi.org/10.1016/j.jas.2009.09.024

645 Figueiral, I., Bouchette, A., Rovira, N., Ivorra, S., Lacombe, T., ... \& Terral, J.F. 2013. 646 Bioarchaeological insights into the process of domestication of grapevine (Vitis vinifera L.) during 647 Roman times in Southern France. PLoS One. 8(5), e63195. doi.org/10.1371/journal.pone.0063195

648 Forni, G. (2012). The origin of "Old World" viticulture. Vitis. 51, 27-38. 
Fuentes, J. M., Gallego, E., García, A. I., Ayuga, F. 2010. New uses for old traditional farm buildings: The case of the underground wine cellars in Spain. Land Use Policy. 27(3), 738-748. doi.org/10.1016/j.landusepol.2009.10.002

652 Fuller, D.Q., Stevens, C.J. 2019. Between domestication and civilization: the role of agriculture and arboriculture in the emergence of the first urban societies. Veg. Hist. Archaeobot. 28(3), 263282. doi.org/10.1007/s00334-019-00727-4

Galet, P. 2000. [Encyclopedic dictionary of grape varieties] Dictionnaire encyclopédique des 656 cépages, Hachette. French.

657 Gómez Bellard, C., Guérin, P., Pérez Jordà, G. 1993. [Evidence of wine production in pre-Roman 658 Spain] Témoignage d'une production de vin dans l' Espagne préromaine. La production du vin et 659 l' huile en Mediterranée: [Actes du Symposium International, (Aix-en-Provence et Toulon, 20-22 660 novembre 1991)]. Ecole Francaise d' Athènes, Athens, pp. 379-395. French.

661 González de Canales, F., Serrano, L., Llompart, J. 2006. The precolonial Phoenician emporium of 662 Huelva ca 900-770 BC. BABesch. 81, 13-29.

663 Grassi, F., Labra, M., Imazio, S., Spada, A., Sgorbati, S., Scienza, A., Sala, F. 2003. Evidence of 664 a secondary grapevine domestication centre detected by SSR analysis. Theor. Appl. Genet. 107(7), 665 1315-1320. doi.org/10.1007/s00122-003-1321-1

666 Guasch-Jané, M. R. 2019. Grape Archaeology and Ancient DNA Sequencing, in: Cantu, D., 667 Walker, M.A. (Eds.), The Grape Genome. Springer, Cham, pp. 57-75. doi.org/10.1007/978-3-030668 18601-2_4

669 Imazio, S., Labra, M., Grassi, F., Scienza, A., Failla, O. 2006. Chloroplast microsatellites to 670 investigate the origin of grapevine. Genet. Resour. Crop Ev. 53(5), 1003-1011. 671 doi.org/10.1007/s10722-004-6896-0

672 Iriarte-Chiapusso, M.J., Ocete-Pérez, C. A., Hernández-Beloqui, B., Ocete-Rubio, R. 2017. Vitis 673 vinifera in the Iberian Peninsula: a review. Plant Biosyst. 151(2), 245-257. 674 doi.org/10.1080/11263504.2016.1165751

675 Jacquat, C., Martinoli, D. 1999. Vitis vinifera L.: wild or cultivated? Study of the grape pips found 676 at Petra, Jordan; 150 BC-AD 40. Veg. Hist. Archaeobot. 8(1-2), 25-30.

677 Kuhl, F. P., Giardina, C.R. 1982. Elliptic Fourier features of a closed contour. Comput. Graph. 678 Image Process. 18(3), 236-258. doi.org/10.1016/0146-664X(82)90034-X

679 Levadoux, L. 1956. [Wild and cultivated populations of Vitis vinifera L.] Les populations sauvages 680 et cultivées de Vitis vinifera L. Annales de l'Amélioration des Plantes. 6(1), 59-117. French.

681 López-Ruiz, C., Doak, B. (Eds.) 2019. Oxford Handbook of the Phoenician and Punic 682 Mediterranean, Oxford University Press, Oxford. 
Mangafa, M., Kotsakis, K. 1996. A new method for the identification of wild and cultivated charred grape seeds. J. Archaeol. Sci. 23(3), 409-418. doi.org/10.1006/jasc.1996.0036

Margaritis, E., Jones, M. 2006. Beyond cereals: crop processing and Vitis vinifera L. Ethnography, experiment and charred grape remains from Hellenistic Greece. J. Archaeol. Sci. 33(6), 784-805. doi.org/10.1016/j.jas.2005.10.021

McGovern, P.E. 2003. Ancient Wine: The Search for the Origins of Viticulture. Princeton University Press, Princeton (NJ).

McGovern, P., Jalabadze, M., Batiuk, S., Callahan, M. P., Smith, K. E., Hall, G. R., Kvavadze, E., Maghradze, D., Rusishvili, N., Bouby, L., Failla, O., Cola, G., Mariani, L., Boaretto, E., Bacilieri, R., This, P., Wales, N., Lordkipanidze, D. 2017. Early neolithic wine of Georgia in the South Caucasus. P. Natl. Acad. Sci. 114(48), E10309-E10318. doi.org/10.1073/pnas.1714728114

Miller, N.F. 2008. Sweeter than wine? The use of the grape in early western Asia. Antiquity. 82, 937-946. doi.org/10.1017/S0003598X00097696

Moricca, C., Nigro, L., Masci, L., Pasta, S., Cappella, F., Spagnoli, F., Sadori, L. 2021. Cultural landscape of the Phoenician Motya (Western Sicily, Italy) inferred by a disposal pit. Veg. Hist. Archaeobot. doi.org/10.1080/14614103.2020.1852757

Moricca C., Nigro L., Spagnoli F., Sabatini S., Sadori L. 2020. Plant assemblage of the Phoenician sacrificial pit by the Temple of Melqart/Herakles (Motya, Sicily, Italy). Environ. Archaeol. 1-13. doi.org/10.1080/14614103.2020.1852757

Myles, S., Boyko, A. R., Owens, C. L., Brown, P. J., Grassi, F., Aradhya, M. K., Prins, B., Reynolds, A., Chia, J.M., Ware, D., Bustamante, C.D., Buckler, E.S. 2011. Genetic structure and domestication history of the grape. P. Natl. Acad. Sci. 108(9), 3530-3535. doi.org/10.1073/pnas.1009363108

Negi, S. S., Olmo, H. P. 1966. Sex conversion in a male Vitis vinifera L. by a kinin. Science 152(3729), 1624-1624.

Nigro, L. 2018. La Sapienza a Mozia 2010-2016: il primo insediamento fenicio, l'area sacra di Baal e Astarte, il Tofet, la necropoli, l'abitato, i nuovi scavi alle mura - una sintesi, in: Guirguis, M. (Ed.), From the Mediterranean to the Atlantic: people, goods and ideas between East and West, II. $8^{\text {th }}$ international congress of Phoenician and Punic studies, Italy, Sardinia, Carbonia, Sant'Antioco 2 $1^{\text {th }}-26^{\text {th }}$ October 2013 (Folia Phoenicia 2), Pisa-Roma 2018, pp. 253-277.

Nigro, L., Spagnoli, F. 2017. Landing on Motya. The earliest Phoenician settlement of the $8^{\text {th }}$ century BC and the creation of a West Phoenician cultural identity in the excavations of Rome «La Sapienza» University - 2012-2016. Stratigraphy, architecture, and finds. Quaderni di Archeologia Fenicio-Punica/Colour Monograph 04, Missione archeologica a Mozia, Rome. 
717 Oksanen, J., Blanchet, F.G., Friendly, M., Kindt, R., Legendre, P., McGlinn, D., Minchin, P.R., 718 O'Hara, R.B., Simpson, G.L., Solymos, P., Stevens, M.H.H., Szoecs, E., Wagner, H. 2019. vegan: 719 Community Ecology Package. $\mathrm{R}$ package version 2.5-6. https://CRAN.R720 project.org/package $=$ vegan

721 Orrù, M., Grillo, O., Lovicu, G., Venora, G., Bacchetta, G. 2013. Morphological characterisation 722 of Vitis vinifera L. seeds by image analysis and comparison with archaeological remains. Veg. 723 Hist. Archaeobot. 22(3), 231-242. doi.org/10.1007/s00334-012-0362-2

724 Pagnoux, C., Bouby, L., Valamoti, S. M., Bonhomme, V., Ivorra, S., Gkatzogia, E., ... \& Terral, 725 J. F. 2021. Local domestication or diffusion? Insights into viticulture in Greece from Neolithic to 726 Archaic times, using geometric morphometric analyses of archaeological grape seeds. J. Archaeol. 727 Sci. 125, 105263.

728 Pagnoux, C., Bouby, L., Ivorra, S., Petit, C., Valamoti, S. M., Pastor, T., Picq, S., Terral, J. F. 729 2015. Inferring the agrobiodiversity of Vitis vinifera L.(grapevine) in ancient Greece by 730 comparative shape analysis of archaeological and modern seeds. Veg. Hist. Archaeobot. 24(1), 75731 84. doi.org/10.1007/s00334-014-0482-y

732 Pecci, A., Borgna, E., Mileto, S., Dalla Longa, E., Bosi, G., Florenzano, A., ... \& Vidale, M. 2020. 733 Wine consumption in Bronze Age Italy: combining organic residue analysis. J. Archaeol. Sci. 123, 734105256.

735 Pérez-Jordà, G., Peña-Chocarro, L., Fernández, M.G., Rodríguez, J.C.V. 2017. The beginnings of 736 fruit tree cultivation in the Iberian Peninsula: plant remains from the city of Huelva (southern 737 Spain). Veg. Hist. Archaeobot. 26(5), 527-538. doi.org/10.1007/s00334-017-0610-6

738 Pérez-Jordà, G., Peña-Chocarro, L., Pardo-Gordó, S. 2021. Fruits arriving to the west. Introduction 739 of cultivated fruits in the Iberian Peninsula. J. Archaeol. Sci. Rep. 35, 102683.

740 Pérez Jordà, G., Mata Parreño, C., Moreno Martín, A., Quixal Santos, D. 2013. Stone wine presses 741

742

743

744 745

746

747 and cellars in the Iberian Iron Age territory of Kelin (Utiel-Requena, València) $\left(6^{\text {th }}-2^{\text {nd }}\right.$ centuries BC), in: Martínez Valle, A. (Ed.), Paisajes y Patrimonio Cultural del Vino y otras bebidas psicotrópicas. Requena 12-15 abril 2011. Ayto. Requena, pp. 149-158.

Portas, L., Farina, V., Del Vais, C., Carcupino, M., Gazza, F., Sanna, I., Zedda, M. 2015. Anatomical study of animal remains from Phoenician-Punic amphorae found in the Santa Giusta Pond, Sardinia (Italy). J. Biol. Res. 88(2), 5073.

Portillo, M., Ball, T.B., Wallace, M., Murphy, C., Pérez-Díaz, S., Ruiz-Alonso, M., Aceituno, F.J., López-Sáez, J.A. 2020. Advances in morphometrics in archaeobotany. Environ. Archaeol. 25(2), 246-256. doi.org/10.1080/14614103.2019.1569351

750 Ramos-Madrigal, J., Runge, A.K.W., Bouby, L., Lacombe, T., Castruita, J.A.S., Adam-Blondon, 751 A.F., Figueiral, I., Hallavant, C., Martìnez-Zapater, J.M., Schaal, C., Töpfer, R., Petersen, B., 
Sicheritz-Pontén, T., This, P., Bacilieri, R., Gilbert, M.P.T., Wales, N. 2019. Palaeogenomic insights into the origins of French grapevine diversity. Nat. Plants. 5(6), 595-603. doi.org/10.1038/s41477-019-0437-5

Riaz, S., De Lorenzis, G., Velasco, D., Koehmstedt, A., Maghradze, D., Bobokashvili, Z., Musayev, M., Zdunic, G., Laucou, V., Walker, M.A., Failla, O., Preece, J.E., Aradhya, M., ArroyoGarcia, R. 2018. Genetic diversity analysis of cultivated and wild grapevine (Vitis vinifera L.) accessions around the Mediterranean basin and Central Asia. BMC Plant Biol. 18(1), 137. doi.org/10.1186/s12870-018-1351-0

Rivera, D., Miralles, B., Obón, C., Carreño, E., Palazón, J.A. 2007. Multivariate analysis of Vitis subgenus Vitis seed morphology. Vitis. 46(4), 158.

Rohlf, F.J., Bookstein, F.L. 1990. Proceedings of the Michigan morphometrics workshop, in: Rohlf, F.J., Bookstein, F.L. (Eds.). University of Michigan, Ann Arbor, pp. 396.

Ros, J., Evin, A., Bouby, L., Ruas, M.P. 2014. Geometric morphometric analysis of grain shape and the identification of two-rowed barley (Hordeum vulgare subsp. distichum L.) in southern France. J. Archaeol. Sci. 41, 568-575. doi.org/10.1016/j.jas.2013.09.015

Ruiz-Gálvez Priego, M. 1986. [Navigation and trade between the Atlantic and the Mediterranean in the late Bronze Age] Navegación y comercio entre el Atlántico y el Mediterráneo a fines de la Edad del Bronce. Trabajos de Prehistoria. 43(1), 9-42. Spanish.

Ruiz-Gálvez Priego, M. 2014. Before the 'Gates of Tartessos': indigenous knowledge and exchange networks in the Late Bronze Age Far West, in: Knapp, A.B., van Dommelen, P. (Eds.), The Cambridge Prehistory of the Bronze \& Iron Age Mediterranean. Cambridge University Press, New York, pp. 196-214.

R Core Team. 2020. R: A Language and Environment for Statistical Computing. Vienna: R Foundation for Statistical Computing. URL https://www.R-project.org

Sabato, D., Esteras, C., Grillo, O., Picó, B., Bacchetta, G. 2015a. Seeds morpho-colourimetric analysis as complementary method to molecular characterization of melon diversity. Sci. Horticul. 192, 441-452. doi.org/10.1016/j.scienta.2015.06.006

Sabato, D., Masi, A., Pepe, C., Ucchesu, M., Peña-Chocarro, L., Usai, A., Giachi, G., Capreti, C., Bacchetta, G. 2015b. Archaeobotanical analysis of a Bronze Age well from Sardinia: A wealth of knowledge. Plant Biosyst. 149, 205-215. doi.org/10.1016/j.scienta.2015.06.006

Sabato, D., Peña-Chocarro, L., Ucchesu, M., Sarigu, M., Del Vais, C., Sanna, I., Bacchetta, G. 2019. New insights about economic plants during the 6th-2nd centuries BC in Sardinia, Italy. Veg. Hist. Archaeobot. 28(1), 9-16. 
Scienza, A. 2008. [Origins and History] Origini e Storia, in: Angelini, R. (Ed.), La vite e il vino. ART S.p.A., Bologna, pp. 48-87. Italian.

Scienza, A., Failla, O. 2016. [Varietal circulation of vines in the Mediterranean: the state of research] La circolazione varietale della vite nel Mediterraneo: lo stato della ricerca. Atti Viterbo. 31-47. Italian.

Smith, H., Jones, G. 1990. Experiments on the effects of charring on cultivated grape seeds. J. Archaeol. Sci. 17(3), 317-327.

Stiglitz, A. 2007. Fenici e Nuragici nell'entroterra tharrense. Sardinia, Corsica et Baleares Antiquae. 5, 87-98. Italian.

Stummer, A. 1911. [On the prehistory of the vine and viticulture] Zur Urgeschichte der Rebe und des Weinbaues. Mitteilungen der Anthropologischen Gesellschaft in Wien. 61, 283-296. German.

Terral, J. F., Tabard, E., Bouby, L., Ivorra, S., Pastor, T., Figueiral, I., Picq, S., Chevance, J.B., Jung, C., Fabre, L., Tardy, C., Compan, M., Bacilieri, R., Lacombe, T., This, P. 2010. Evolution and history of grapevine (Vitis vinifera) under domestication: new morphometric perspectives to understand seed domestication syndrome and reveal origins of ancient European cultivars. Ann. Bot. 105(3), 443-455. doi.org/10.1093/aob/mcp298

This, P., Lacombe, T., Thomas, M.R. 2006. Historical origins and genetic diversity of wine grapes. Trends Genet. 22(9), 511-519. doi.org/10.1016/j.tig.2006.07.008

Ucchesu, M., Orru, M., Grillo, O., Venora, G., Usai, A., Serreli, P. F., Bacchetta, G. 2015. Earliest evidence of a primitive cultivar of Vitis vinifera L. during the Bronze Age in Sardinia (Italy). Veg. Hist. Archaeobot. 24(5), 587-600. doi.org/10.1007/s00334-014-0512-9

Ucchesu, M., Orrù, M., Grillo, O., Venora, G., Paglietti, G., Ardu, A., Bacchetta, G. 2016. Predictive method for correct identification of archaeological charred grape seeds: support for advances in knowledge of grape domestication process. PLoS One.11(2), e0149814. doi.org/10.1371/journal.pone.0149814

Van Dommelen, P., Ramis, D., Roppa, A., Stiglitz, A. 2020. [S'Urachi Project: cultural encounters around a Phoenician-Punic Nuraghe] Progetto S'Urachi: incontri culturali intorno a un Nuraghe de età Fenicio-Punica, in: Celestino Pérez, S., Rodríguez, A. (Eds.), IX Congreso Internacional de Estudios Fenicios y Púnicos. CSIC, Mérida, pp. 1627-1636. Italian. Vera Rodríguez, J.C., Echevarría Sánchez, A 2013. Sistemas agrícolas del I milenio a.C. en el yacimiento de La OrdenSeminario de Huelva. Viticultura protohistórica a partir del análisis arqueológico de las huellas de cultivo. In: Celestino Pérez S, Blánquez Pérez J (Eds.) Patrimonio cultural de la vid y el vino. Universidad Autónoma de Madrid, Madrid, pp. 95-106.

Wallace, M., Bonhomme, V., Russell, J., Stillman, E., George, T. S., Ramsay, L., Wishart, J., Timpany, S., Bull, H., Booth, A., Martin, P. 2019. Searching for the origins of bere barley: a 
820 geometric morphometric approach to cereal landrace recognition in archaeology. J. Archaeol.

821 Method Th. 26(3), 1125-1142. doi.org/10.1007/s10816-018-9402-2

822

823 Supplementary materials

824 Supplementary material 1. PCA of waterlogged archaeological samples.

825 Supplementary material 2. PCA of charred archaeological samples. 


\section{Supplementary Material 1}

Archaeological waterlogged PCA

0.010

0.005

ত

(1) 0.000

$-0.005$

- HUELVA_4093

$\begin{array}{ll}-0.02 & -0.01\end{array}$

0.00

PC1

site

- HUELVA

- SURAC 
Supplementary Material 2

Archaeological charred PCA

0.01 MOTYA_US1406

0.00

MOTYA_US1112

U

$-0.01$

$-0.02$

$-0.03$ MOTYA_US2268

MOTYA_US1492 site

- MOTYA

MOTYA_US1407•

$-0.02$

0.00

0.02

PC1

0.04

0.06 